\title{
Interacting effects of forest fragmentation and howler monkey foraging on germination and disperal of fig seeds
}

\author{
Juan Carlos Serio-Silva and Victor Rico-Gray
}

\begin{abstract}
We studied changes in germination rates and dispersal distance of seeds of Ficus perforata and F. lundelli dispersed by howler monkeys (Alouatta palliata mexicana), in a small (40 ha) 'disturbed' and a larger (>600 ha) 'preserved' tropical rainforest in southern Veracruz, Mexico. The interaction between A.p. mexicana and Ficus (Urostigma) spp. is beneficial for the interacting species and has important implications for their conservation. Howler monkeys gain from the ingestion of an important food source, germination rates of Ficus seeds are improved by passage through the monkeys' digestive tract, and the seeds are more likely to be deposited in a site suitable for germination and development. Seed dispersal distances are relatively larger in the preserved site, with both the size of the forest area and the spatial pattern of Ficus affecting the dispersal process.
\end{abstract}

In a large forest fragment with 'regularly' distributed Ficus individuals the howler monkeys move away from the seed source, increasing the probability that the seeds are desposited on a tree other than Ficus, which is important for the germination and future development of a hemiepiphytic species. In a small forest fragment with trees distributed in clumps howlers repeatedly use the same individual trees, and faeces containing seeds may be dropped on unsuitable trees more often. These are key issues when addressing conservation policies for fragmented forests.

Keywords Alouatta palliata mexicana, Ficus, fragmentation, howler monkeys, interspecific interactions, Mexico, seed germination, tropical forest.

\section{Introduction}

Recent studies suggest that one of the most important aspects to be considered in programmes for the conservation of tropical forests is the identification of ecological interactions among the important species in the ecosystem (Thompson, 1994; Howe \& Miriti, 2000) and the evaluation of how these processes are altered by habitat fragmentation (Nathan \& Muller-Landau, 2000). Given the current rate of tropical forest clearing, an important conservation issue is how forest fragments are altered by changes in the seed dispersal activities of the frugivores that the fragments support. Understanding the cascading effects of fragmentation will assist in the construction of informed management plans for such habitats.

Figs (Ficus spp., Moraceae) are an important food source for invertebrates and vertebrates, including bats, birds and monkeys, all of which may be seed dispersal agents (Banaccorso, 1979; Janzen, 1979; Gautier-Hion

Juan Carlos Serio-Silva' (Corresponding author) and Victor Rico-Gray Departamento de Ecología Vegetal, Instituto de Ecología, A.C., Apdo. 63, Xalapa, Veracruz, 91070 México

${ }^{1}$ Present address: División Académica de Ciencias Biológicas, Universidad Juárez Autónoma de Tabasco, Km. 0.5 carretera Villahermosa-Cárdenas, Villahermosa, Tabasco 86039, México. E-mail: serioju@ecologia.edu.mx

Received 29 January 2001. Revision requested 11 June 2001 Accepted 7 February 2002. et al., 1985; de Figueiredo, 1993). Frugivore strategies and the interactions between fruiting plants, including figs, and primate dispersers have been documented for Pongo pygmaeus in Asia (Galdikas, 1982), for Papio anubis and Gorilla gorilla gorilla in Africa (Lieberman et al., 1979; Tutin et al., 1991), and for Alouatta palliata mexicana, A. p. palliata, Cebus capucinus, Saguinus mystax and S. fuscicollis in the neotropics (Howe, 1980; Estrada \& Coates-Estrada, 1984, 1986, 1991; Garber, 1986). Figs are one of the most important food sources for primates (Milton, 1980; Terborgh, 1986; Serio-Silva, 1996; Silver et al., 1998), particularly during periods of general food scarcity (Terborgh, 1983, 1986; Wrangham et al., 1993). Fig trees contribute young and mature leaves, and particularly fruits, to the diet of howler monkeys (Alouatta spp.) (Milton, 1980; Serio-Silva, 1996, 1997; Silver et al., 1998). However, the specific associations between these primates and Ficus species have been little studied (but see de Figueiredo, 1993; Wrangham et al., 1993), and we do not know how seed dispersal and germination are altered by changes resulting from forest fragmentation, and how this knowledge can be applied to tropical forest conservation programmes.

Figs occur in tropical and subtropical areas worldwide, and the genus Ficus is one of the most numerous in species (c. 800) among woody plants. Many of these species (c. 280), within the subgenus Urostigma (Putz \& Holbrook, 1986), are hemiepiphytic 'stranglers'; their 
seeds germinate on a host or support tree, and the young plants later send roots to the soil. Howler monkeys use the forest canopy for their daily activities, and so faeces containing seeds of Urostigma are deposited on host trees (e.g. in branch forks, depressions and on bark).

As a result of their phenology figs are regarded as keystone species in many tropical rainforests, representing a source of food and shelter in times when other species are scarce (Terborgh, 1986; McKey, 1989), although this may not be true under all circumstances (Gautier-Hion \& Michaloud, 1989). It has been suggested that, as a consequence of flowering asynchrony, figs are particularly vulnerable to forest fragmentation and reduction in habitat area (Janzen, 1986; McKey, 1989). Other observations suggest that in fragmented forests figs, and especially hemiepiphytic figs, may be more vulnerable to extinction than other tropical forest tree species because their minimum viable population size is relatively large and adults often occur at low densities (McKey, 1989). When forests become fragmented frugivores often disappear (Andrén, 1994), and fig seeds thus lose their dispersal agents. Figs in fragmented forests are dependent on the behaviour of seed dispersers, which may alter the shape of the seed shadow (i.e. the spatial distribution of seeds following dispersal; McKey, 1989). If monkeys that are restricted to mature forest are important dispersal agents for a particular fig species, the seed shadow may be truncated by forest fragmentation, because these animals will remain in the forest fragment and no seeds will be carried elsewhere. Bats or birds, in contrast, may carry fig seeds from one forest fragment to another, with some seeds being dropped in unsuitable habitats between fragments (Galindo-González, 1998).

It is generally accepted that fig seeds pass undamaged through the digestive tracts of many frugivores. However, few quantitative studies have been made on the role of howler monkeys as dispersal agents and their effect on the germination of fig seeds (Estrada \&
Coates-Estrada, 1986; de Figueiredo, 1993). In this paper we address a part of the dispersal process, namely we analyze the effect of Mexican howler monkeys Alouatta palliata mexicana on the germination success and dispersal distances of seeds of the strangler figs Ficus perforata and F. lundelli, and how these interactions differ between a 'disturbed' and a 'preserved' habitat. We then discuss the potential role that this interaction plays in the complex process of forest regeneration (Zuidema et al., 1996; Howe \& Miriti, 2000), and in particular the effect of forest fragmentation on the interaction.

\section{Methods}

Field observations and seed sampling were carried out between January 1998 and June 1999 in a 'disturbed' and a 'preserved' site in south-eastern Veracruz, México (Fig. 1, Table 1). The disturbed site was a relatively small isolated forest patch (40 ha), modified by humans and used for extraction of plant species, agriculture and cattle raising, located in Playa Escondida, San Andrés Tuxtla, Veracruz, México $\left(18^{\circ} 35^{\prime} \mathrm{N}, 95^{\circ} 03^{\prime} \mathrm{W}\right)$. The preserved site is a large, relatively undisturbed area, of

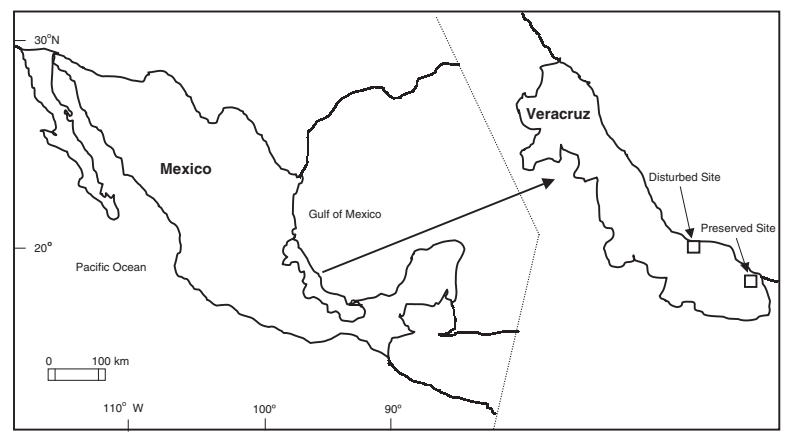

Fig. 1 Location of the two study sites in southern Veracruz, México: the 'disturbed' site at Playa Escondida and the'preserved' site in the Carolino Anaya reserve.

Table 1 Characteristics of the two study sites.

\begin{tabular}{|c|c|c|}
\hline Parameter & 'Disturbed' site & 'Preserved' site \\
\hline Area & 40 ha & 600 ha \\
\hline Climate & Warm, subhumid & Warm, humid \\
\hline Annual precipitation & $2,000 \mathrm{~mm}$ & $2,500 \mathrm{~mm}$ \\
\hline Temperature (max-mean-min) & $39.5-25.1-9^{\circ} \mathrm{C}$ & $43.5-25.5-18^{\circ} \mathrm{C}$ \\
\hline Altitude & $70 \mathrm{~m}$ & $50 \mathrm{~m}$ \\
\hline Vegetation type & Mostly patches of secondary forest & Primary forest \\
\hline Major plant families & Moraceae, Cecropiaceae, Fabaceae & Moraceae, Rubiaceae, Orchidaceae, Fabaceae \\
\hline Density of Ficus perforata & $1.2 \mathrm{ha}^{-1}$ & $0.2 \mathrm{ha}^{-1}$ \\
\hline Density of Ficus lundelli & $0.9 \mathrm{ha}^{-1}$ & $0.1 \mathrm{ha}^{-1}$ \\
\hline Number of howler troops & 4 & 8 \\
\hline Howler density & $1.05 \mathrm{ha}^{-1}$ (4 troops, 42 ind.) & $0.12 \mathrm{ha}^{-1}$ (8 troops, 74 ind.) \\
\hline Home range per troop & 10 ha & 75 ha \\
\hline
\end{tabular}


which 600 ha are protected from human activities; it is connected with other forested areas, and is one of the best preserved areas of tropical rainforest in southern Veracruz. This 600 ha area lies within the Carolino Anaya Reserve, near Coatzacoalcos, Veracruz, México $\left(18^{\circ} 07^{\prime} \mathrm{N}, 94^{\circ} 18^{\prime} \mathrm{W}\right)$ (Fig. 1, Table 1).

In the disturbed site there are four howler monkey troops, and in the preserved site there are eight troops. We studied two troops at each site. The two troops selected for study in the disturbed site had eight and nine individuals, and those in the preserved site had eight and 10 individuals, respectively. To estimate the home range of the troops in each site we conducted a preliminary survey following the suggestions of Zucker et al. (1996). The howlers had larger home range sizes and occurred at a lower density in the preserved than in the disturbed habitat (based on estimations by Estrada \& Coates-Estrada, 1984; Table 1).

We determined the spatial pattern of $F$. perforata and F. lundelli at both sites, using the Morisita Index of Dispersion $\left(I_{\mathrm{d}}\right.$, Brower et al., 1989)

$I_{\mathrm{d}}=n\left[\left(\Sigma X^{2}-N\right) /(N(N-1))\right]$

where $n$ is the number of 0.5 ha plots (disturbed site $n=20$, preserved site $n=4), N$ is the total number of individuals counted on all $n$ plots, and $\Sigma X^{2}$ is the square of the number of individuals per plot, summed over all plots $\left(I_{\mathrm{d}}=1.0\right.$ for a 'random' distribution, $I_{\mathrm{d}}=0$ for a 'regular' distribution, and $I_{\mathrm{d}}=n$ at maximum aggregation).

Mature fruits of F. perforata and F. lundelli (c. $2.0 \mathrm{~kg}$ per species per site), and monkey faeces (30 samples per site) were collected from the forest floor. To determine the number of seeds of each fig species deposited in the faeces we selected, from only the most complete and least fragmented faeces, 11 samples containing F. perforata seeds and 9 containing F. lundelli seeds from each study site. Seeds from both faeces and fruits were observed under a microscope to confirm the presence of an embryo; those used by fig wasps (Agaonidae) were discarded. Seeds were washed, dried and weighed. For the germination trials, we randomly selected, from those seeds with confirmed embryos, 1,000 seeds of each species from fruits and 1,000 from faeces, from each study site, giving a total of 4,000 seeds for each species.

Seeds were placed in $9 \mathrm{~cm}$ Petri dishes covered with Whatman 42 filter paper. Forty Petri dishes (50 seeds in each) were allocated per Ficus species, for each study site; 20 dishes were used for seeds from faeces and 20 dishes for seeds from fruits. The Petri dishes were placed for 30 days in a thermostatically controlled chamber with a regime of $16 \mathrm{~h}$ at $27^{\circ} \mathrm{C}$ and $8 \mathrm{~h}$ at $30^{\circ} \mathrm{C}$. Lids were kept in place to minimize evaporation, but distilled water was added at least every three days to maintain humidity. Evidence of germination (appearance of the radicle) was noted every two days until no further germination was observed in seven successive counts. The position of the Petri dishes inside the controlled chamber was modified during each daily survey (one row at a time, from the front to the back of the chamber). We calculated the proportion of seeds germinating per treatment, per species.

To evaluate seed dispersal distance, i.e. from site of fruit ingestion to site of seed defecation, we selected individual trees of F. perforata and F. lundelli where a monkey troop was feeding and, after fruit ingestion, we followed the troop. We allowed for the evacuation of seeds from other trees ingested prior to feeding on the selected individual Ficus. The estimated digestive turnover of howler monkeys is c. $20 \mathrm{~h}$ (Milton et al., 1980), so we followed the selected monkey troop for $24 \mathrm{~h}$ and, for each study site, we measured the linear distance in metres from site of fruit ingestion to site of defecation (9 measurements for F. perforata and 10 measurements for F. lundelli, per site) for seeds deposited after $20 \mathrm{~h}$.

Differences in the proportions of seeds germinating between Ficus species, site and seed source were explored with ANOVA with a logit link function using the GLIM-4 statistical package (Francis et al., 1993; Aitkin et al., 1994). As a result of data overdispersion (adjusted scale parameter $=2.066$ ), the goodness-of-fit was evaluated with an F-test, using a binomial error distribution, and the change in variance compared directly with F-tables to assess its significance (Crawley, 1993; Aitkin et al., 1994). We used $t$-tests (Zar, 1996) to compare the seed dispersal distances between Ficus species and sites.

\section{Results}

We found no significant differences in the number of Ficus seeds in faecal samples between sites (F. perforata, $t=0.615, \mathrm{df}=10, \quad P=0.552 ; \quad F$. lundelli, $t=0.519$, $\mathrm{df}=8, P=0.618$ ) (Table 2). Seeds of both Ficus species germinated after 9-11 days, reached a maximum at about day 16, and ceased germination after 28-30 days. For both sites and species seeds from faeces had a higher germination success than seeds from fruit (Table 2). Seed source had the greatest influence on germination, explaining $87.9 \%$ of the variation in germination (Table 3 ). The species * source interaction also had a significant effect on seed germination (Table 3 ).

The Ficus population in the disturbed site exhibited a clumped spatial pattern $\left(I_{\mathrm{d}}, F\right.$. perforata $=1.25, F$. lundelli $=$ 1.18), whereas in the preserved site the spatial pattern was more 'regular' or uniform $\left(I_{\mathrm{d}}, F\right.$. perforata $=0.79$, F. lundelli $=0.86)$. 
Table 2 Mean number of seeds $( \pm$ SEM) of both Ficus species in howler monkey faeces, germination percentage of seeds from faeces and fruit, and mean seed dispersal distances $( \pm$ SEM) in the 'disturbed' and 'preserved' study sites. Numbers in parentheses are the sample sizes.

\begin{tabular}{llll}
\hline & F. perforata & & F. lundelli \\
\cline { 2 - 3 } Parameter/Site & Disturbed & Preserved & Disturbed \\
\hline Number of seeds in faeces & $2224.8 \pm 111.5(11)$ & $2040.1 \pm 111.5(11)$ & $1917 \pm 110.3(9)$ \\
Seed germination (faeces) & $78 \%(1,000)$ & $72 \%(1,000)$ & $59.5 \%(1,000)$ \\
Seed germination (fruits) & $0 \%(1,000)$ & $0.3 \%(1,000)$ & $9.2 \%(1,000)$ \\
Dispersal distance (m) & $72.71 \pm 21.42(9)$ & $172.25 \pm 15.64(9)$ & $67.4 \pm(1,000)$ \\
\hline
\end{tabular}

Table 3 Analyses of germination proportions with ANOVA, using a logit model with a binomial error to test for differences in the germination of Ficus seeds as a function of species (F. lundelli, F. perforata), site ('disturbed', 'preserved') and source (fruits, faeces); overall $F_{1,152}=3.84, P<0.0001$.

\begin{tabular}{|c|c|c|c|c|c|}
\hline Source of variation & Variance & df & Mean square & $F$ & $P$ \\
\hline Species & 1.545 & 1 & 1.55 & 0.750 & 0.387 \\
\hline Site & 0.0002 & 1 & 0.0002 & 0.001 & 0.976 \\
\hline Source & 2072.00 & 1 & 2072.00 & 1005.800 & $<0.001$ \\
\hline Species * site & 5.77 & 1 & 5.77 & 2.800 & 0.096 \\
\hline Species * source & 119.3 & 1 & 119.30 & 57.900 & $<0.001$ \\
\hline Site ${ }^{*}$ source & 7.44 & 1 & 7.44 & 3.610 & 0.059 \\
\hline Species * site $^{*}$ source & 4.01 & 1 & 4.01 & 1.940 & 0.166 \\
\hline Error & 147.14 & 152 & 0.96 & & \\
\hline Total & 2357.00 & 159 & & & \\
\hline
\end{tabular}

The monkeys deposited seeds from both fig species farther away from the parent tree in the preserved than in the disturbed site ( $F$. perforata, $t=3.374, \mathrm{df}=8$, $p<0.01$; F. lundelli, $t=10.138, \mathrm{df}=9, p<0.01$ ) (Table 2).

\section{Discussion}

Howler monkeys Alouatta palliata mexicana at the two study sites had positive and significant effects on the germination of Ficus seeds, as do Papio anubis (Lieberman et al., 1979), Saguinus mystax and S. fuscicollins (Garber, 1986), A. palliata (Estrada \& Coates-Estrada, 1991), and Pan troglodytes (Wrangham et al., 1993, 1994). Although seed source explained most of the variation in seed germination, the significant source ${ }^{*}$ species interaction showed that each species of Ficus has its own response to passage through the gut.

Dispersal distances differed between sites, being significantly greater in the 'preserved' site. To be sure that this result was not just a consequence of the larger size of this site, we calculated the ratio of dispersal distance (in metres) to number of Ficus individuals per site. This ratio was relatively larger for the preserved site (1.17 vs 0.78). This may be at least partly explained by the differences in distribution pattern of Ficus between the two sites. In the 'disturbed' site both Ficus species have a clumped distribution pattern, whereas in the preserved site they are more regularly distributed. Howler troops constantly move among Ficus trees to monitor and cope with their asynchronous fruiting pattern (Milton, 1980; Serio-Silva, 1996), and troop displacements depend on social structure within a home range of flexible size (Zucker et al., 1996). In the small disturbed site (40 ha) the four monkey troops must divide the fragment into small home ranges (c. $10 \mathrm{ha}$ ), and troops moving through neighbouring home ranges exhibit constant agonistic vocalizations (pers. obs.). The eight troops in the larger preserved site ( $>600 \mathrm{ha}$ ) can occupy home ranges of up to $75 \mathrm{ha}$, and encounters between troops are rare (pers. obs.). Howler monkeys moved relatively shorter distances in the disturbed site, within clumps of Ficus. In the preserved site, however, they moved relatively larger distances among more regularly dispersed trees, and should be more effective in depositing seeds on sites suitable for germination and future establishment, i.e. away from the parent tree, and on tree species other than Ficus (Chapman, 1995).

Many tree species lose large proportions of seeds to the activity of seed predators, and Ficus trees are no exception, losing c. $50 \%$ of their seeds to agaonid wasps (Ramirez, 1976). The efficient dispersal (sensu Fleming \& Sosa, 1994) of the remaining seeds is important for the conservation of Ficus. Primates are an important seed dispersal vector, because they make up $25-40 \%$ of the animal biomass of tropical forests, and in a typical day howler monkeys can ingest a relatively higher volume of Ficus (Urostigma) fruits and seeds than other frugivores such as bats or birds (Coates-Estrada 
\& Estrada, 1986). However, the effect of differences in digestion time and patterns of defecation amongst these vertebrates (e.g., Morrison, 1980; Fleming, 1988; Lambert, 1989a, b; Charles-Dominique, 1991; Midya \& Brahmachary, 1991; Medellín \& Gaona, 1999) on the dispersal and germination of Ficus (Urostigma) seeds has rarely been considered. Howler monkeys ingest and disperse more seeds per faecal unit deposited $(2,015$ seeds per individual in this study) than other sympatric vertebrate frugivores that also ingest Ficus seeds (e.g. bats 154 and birds 294 seeds per individual; Medellín \& Gaona, 1999). Bats, birds and primates may all deposit seeds on the ground, but howler monkeys transport a greater number of seeds per individual and rarely leave the forest, whereas bats and birds transport a limited amount of seeds, and move outside the forested area where seeds may be deposited in unsuitable sites.

The interaction between Alouatta palliata mexicana and Ficus (Urostigma) spp. is beneficial for the interacting species and has important implications for their conservation. Howlers gain from the ingestion of an important food source (Milton, 1980; Terborgh, 1983; Serio-Silva, 1996), and Ficus (Urostigma) seeds attain greater germination success from passage through the digestive tract and are more likely to be deposited in suitable germination sites. Both the size of the forest and the distribution pattern of Ficus individuals can affect the dispersal process. A larger area of forest allows howler monkeys to move away from the seed source, increasing the probability that seeds be deposited on a tree species other than Ficus, which is important for the germination and future development of a hemiepiphytic species. In a small forest fragment howlers repeatedly use the same individual trees, and seeds may be more often dropped on unsuitable trees. These issues need to be considered when developing conservation policies for fragmented forests (Turner, 1996; Zuidema et al., 1996), and it is increasingly important to understand how the interactions between trees and their dispersal agents change with increasing habitat fragmentation and decreasing area of forest.

\section{Acknowledgements}

We thank Albright and Wilson Troy de Mexico for permission to work in the Carolino Anaya Reserve, V.J. Sosa-Fernández, V. Parra-Tabla, R. Manson and two anonymous reviewers for their comments and suggestions on earlier drafts of this manuscript, and J. BelloGutiérrez for his help with the statistical analyses. Research was supported by Instituto de Ecologia, A.C (902-16), equipment donation by Idea Wild and a CONACyT scholarship to JCSS.

\section{References}

Aitkin, M., Anderson, D., Francis, B. \& Hinde, J. (1994) Statistical Modelling in GLIM. Oxford Science Publications, Oxford, UK.

Andrén, H. (1994) Effects of habitat fragmentation on birds and mammals in landscapes with different proportions on suitable habitat; a review. Oikos, 71, 355-366.

Banaccorso, F.J. (1979) Foraging and reproductive ecology in a Panamanian bat community. Bulletin Florida State Museum, Biological Sciences, 24, 59-408.

Brower, E.J., Zar, H.J. \& von Ende, C.N. (1989) Field and Laboratory Methods for General Ecology. W.C. Brown Company Publishers, USA.

Chapman, C.A. (1995) Primate seed dispersal: coevolution and conservation implications. Evolutionary Anthropology, 4, 74-82.

Charles-Dominique, P. (1991) Feeding strategy and activity budgets of the frugivorous bat Carollia perpiscillata (Chiroptera: Phyllostomidae) in French Guyana. Journal of Tropical Ecology, 7, 243-256.

Coates-Estrada, R. \& Estrada, A. (1986) Fruiting and frugivores at a strangler fig in the tropical rain forest of Los Tuxtlas, México. Journal of Tropical Ecology, 2, 349-357.

Crawley, M. (1993) GLIM for Ecologists. Blackwell Scientific Publications, Oxford.

Estrada, A. \& Coates-Estrada, R. (1984) Fruit eating and seed dispersal by howling monkeys (Alouatta palliata) in the tropical rain forest of Los Tuxtlas, Mexico. International Journal of Primatology, 5, 105-131.

Estrada, A. \& Coates-Estrada, R. (1986) Frugivory in howling monkeys (Alouatta palliata) at Los Tuxtlas: seed dispersal and fate of seeds. In Frugivores and Seed Dispersal (ed. A. Estrada \& T.H. Fleming), pp. 93-104. Dr W. Junk Publishers, The Hague, The Netherlands.

Estrada, A. \& Coates-Estrada, R. (1991) Howling monkeys (Alouatta palliata), dung beetles (Scarabaeidae) and seed dispersal; ecological interactions in the tropical rain forest of Los Tuxtlas, Mexico. Journal of Tropical Ecology, 7, 459-474.

de Figueiredo, R.A. (1993) Ingestion of Ficus enormis seeds by howler monkeys (Alouatta fusca) in Brazil: effects on seed germination. Journal of Tropical Ecology, 9, 541-543.

Fleming, T.H. (1988) The Short-Tailed Fruit Bat: A Study in Plantanimal Interactions. University of Chicago Press, Chicago, USA.

Fleming, T.H. \& Sosa, V.J. (1994) Effects of nectarivorous and frugivorous mammals on reproductive success of plants. Journal of Mammalogy, 75, 845-851.

Francis, B., Green, M. \& Payne, C. (1993) The GLIM System: Release 4 Manual. Claredon Press, Oxford, UK.

Galdikas, B.M.F. (1982) Orangutans as seeds dispersers in Tanjung Puting, central Kalimatan: implications for conservation. In The Orangutan. Its Biology and Conservation (ed. L.E.M. de Boer), pp. 285-299. Junk Publishers, Dordrecht, The Netherlands.

Galindo-González, J. (1998) Dispersión de semillas por murciélagos: su importancia en la conservación y regeneración del bosque tropical. Acta Zoológica Mexicana (nueva serie), 73, 57-74.

Garber, P.A. (1986) The ecology of seed dispersal in two species of callitrichid primates (Saguinus mystax and Saguinus fuscicollis). American Journal of Primatology, 10, 155-170. 
Gauthier-Hion, A., Duplantier, J.M., Feer, F., Sourd, C., Decoux, J.P., Dubost, G., Emmons, L., Erard, C., Hecketsweiler, P., Moungazi, A., Roussilhon, C. \& Thiollay, J.M. (1985) Fruit characters as basis of fruit choice and seed dispersal in a tropical forest vertebrate community. Oecologia, 65, 324-337.

Gautier-Hion, A. \& Michaloud, G. (1989) Are the figs always keystone resources for tropical frugivores vertebrates? A test in Gabon. Ecology, 70, 1826-1833.

Howe, H.F. (1980) Monkey dispersal and waste of a neotropical fruit. Ecology, 61, 944-959.

Howe, H.F. \& Miriti, M.N. (2000) No question: seed dispersal matters. Trends in Ecology and Evolution, 15, 434-436.

Janzen, D.H. (1979) How to be a fig. Annual Review of Ecology and Systematics, 10, 13-51.

Janzen, D.H. (1986) Mice, big mammals, and seeds: it matters who defecates where. In Frugivores and Seed Dispersal (eds A. Estrada \& T.H. Fleming), pp. 261-271. Dr W. Junk, Dordrecht, Netherlands.

Lambert, F. (1989a) Fig eating by birds in a malaysian lowland rainforest. Journal of Tropical Ecology, 5, 410-412.

Lambert, F. (1989b) Pigeons as seed predators and dispersers of a fig in a Malaysian lowland forest. Ibis, 131, 512-527.

Lieberman, D., Hall, J.B., Swaine, M.D. \& Lieberman, M. (1979) Seed dispersal by baboons in the Shai Hills, Ghana. Ecology, 60, 65-75.

McKey, D.B. (1989) Population biology of figs: applications for conservation. Experientia, 45, 661-673.

Medellín, R.A. \& Gaona, O. (1999) Seed dispersal by bats and birds in forest and disturbed habitats of Chiapas, México. Biotropica, 31, 478-485.

Midya, S. \& Brahmachary, R.L. (1991) The effect of bird upon germination of banyan (Ficus bengalensis) seeds. Journal of Tropical Ecology, 7, 537-538.

Milton, K. (1980) The Foraging Strategy of Howler Monkeys: A Study in Primate Economics. Columbia University Press, New York, USA.

Milton, K., van Soest, P.J. \& Robertson, J.B. (1980) Digestive efficiencies of wild howler monkeys. Physiological Zoology, 53, 402-409.

Morrison, D.W. (1980) Foraging and day-roosting dynamics of the canopy fruit bats in Panama. Journal of Mammalogy, 61, $20-29$.

Nathan, R. \& Muller-Landau, H.C. (2000) Spatial patterns of seed dispersal, their determinants and consequences for recruitment. Trends in Ecology and Evolution, 15, 278-285.

Putz, F.E. \& Holbrook, N.M. (1986) Notes on the natural history of hemiepiphytes. Selbyana, 9, 61-69.

Ramirez, B.W. (1976) Germination of seeds of new world Urostigma (Ficus) and Morus rubra L. (Moraceae). Revista de Biología Tropical, 24, 1-6.

Serio-Silva, J.C. (1996) Calidad del alimento consumido por Alouatta palliata mexicana en condiciones de semilibertad. MSc thesis, Instituto de Neuroetología, Universidad Veracruzana, Xalapa, México.

Serio-Silva, J.C. (1997) Studies of howler monkeys (Alouatta palliata) translocated to a neotropical rain forest fragment.
I. Social distance in translocated howler monkeys, II. Activity patterns and feeding habits of translocated howler monkeys. Laboratory Primate Newsletter, 36, 11-14.

Silver, S.C., Ostro, L.E.T., Yeager, C.P. \& Horwich, R. (1998) Feeding ecology of the black howler monkey (Alouatta pigra) in northern Belize. American Journal of Primatology, 45, 263-270.

Terborgh, J. (1983) Five New World Primates. A Study in Comparative Ecology. Princeton University Press, Princeton, New Jersey, USA.

Terborgh, J. (1986) Keystone plant resources in the tropical rain forest. In Conservation Biology (ed. M. Soulé), pp. 330-344. Sinauer associates, Sunderland, USA.

Thompson, J.N. (1994) The Coevolutionary Process. University of Chicago Press, Chicago, USA.

Turner, I.M. (1996) Species loss in a fragment of tropical rain forest: a review of the evidence. Journal of Applied Ecology, 33, 200-204.

Tutin, C.E.G., Williamson, E.A., Rogers, M.E. \& Fernández, M. (1991) A case study of a plant animal relationship: Cola lizae and lowland gorillas in the Lope Reserve, Gabon. Journal of Tropical Ecology, 7, 181-199.

Wrangham, R.W., Conklin, N.L., Etot, G., Obua, J., Hunt, K.D., Hauser, M.D. \& Clark, A.P. (1993) The value of figs to chimpanzees. International Journal of Primatology, 14, 243-256.

Wrangham, R.W., Chapman, C.A. \& Chapman, L.J. (1994) Seed dispersal of forest chimpanzees. Journal of Tropical Ecology, 10, 355-368.

Zar, J. (1996) Biostatistical Analysis. Prentice Hall, Englewood Cliffs, New Jersey, USA.

Zucker, E.L., Clarke, M.R., Glander, K.E. \& Scott, Jr., N.J. (1996) Sizes of home ranges and howling monkey groups at hacienda La Pacífica, Costa Rica: 1972-1991. Brenesia, 45-46, 153-156.

Zuidema, P.A., Sayer, J.A. \& Dijkman, W. (1996) Forest fragmentation and biodiversity: the case for intermediatesized conservation areas. Environmental Conservation, 23, 290-297.

\section{Biographical sketches}

Juan Carlos Serio Silva is currently completing his $\mathrm{PhD}$ in Ecology and Management of Natural Resources at Instituto de Ecología, AC, Xalapa, Veracruz, México. His research since 1989 has mainly focused on primate behavioural ecology and conservation, especially animal-plant interactions.

Dr Victor Rico-Gray is a senior research scientist at the Plant Ecology Department of Instituto de Ecología, AC. With the late Elizabeth S. Watts, he was one of the pioneers of primate studies in the Yucatan Peninsula, México. Currently, his research focuses on the ecology of ant-plant interactions and their seasonal and geographic variation. 